\title{
GMR
}

\section{Myrciaria dubia, an Amazonian fruit: population structure and its implications for germplasm conservation and genetic improvement}

\author{
C.F. Nunes ${ }^{1}$, T.A. Setotaw ${ }^{2}$, M. Pasqual ${ }^{2}$, E.A. Chagas ${ }^{3}$, E.G. Santos ${ }^{4}$, \\ D.N. Santos ${ }^{2}$, C.G.B. Lima ${ }^{3}$ and G.M.A. Cançado ${ }^{5}$ \\ ${ }^{1}$ Instituto de Ciências Agrárias, Universidade Federal de Minas Gerais, \\ Montes Claros, MG, Brasil \\ ${ }^{2}$ Departamento de Agricultura, Universidade Federal de Lavras, Lavras, \\ MG, Brasil \\ ${ }^{3}$ Centro de Pesquisa Agroflorestal de Roraima, \\ Empresa Brasileira de Pesquisa Agropecuária, Boa Vista, RR, Brasil \\ ${ }^{4}$ Laboratório de Biotecnologia Vegetal, \\ Empresa de Pesquisa Agropecuária de Minas Gerais, Caldas, MG, Brasil \\ ${ }^{5}$ Unidade Mista de Pesquisa em Genômica Aplicada a Mudanças Climáticas, \\ Empresa Brasileira de Pesquisa Agropecuária, Campinas, SP, Brasil \\ Corresponding author: C.F. Nunes \\ E-mail: claudineia.f.nunes@gmail.com
}

Genet. Mol. Res. 16 (1): gmr16019409

Received October 6, 2016

Accepted December 12, 2016

Published March 22, 2017

DOI http://dx.doi.org/10.4238/gmr16019409

Copyright (C) 2017 The Authors. This is an open-access article distributed under the terms of the Creative Commons Attribution ShareAlike (CC BY-SA) 4.0 License

\begin{abstract}
Myrciaria dubia (camu-camu) is an Amazon tree that produces a tart fruit with high vitamin $\mathrm{C}$ content. It is probably the fruit with the highest vitamin $\mathrm{C}$ content among all Brazilian fruit crops and it can be used to supplement daily vitamin $\mathrm{C}$ dose. This property has attracted the attention of consumers and, consequently, encouraged fruit farmers to produce it. In order to identify and select potential accessions for commercial exploitation and breeding programs, $M$.
\end{abstract}

Genetics and Molecular Research 16 (1): gmr16019409 
dubia has received considerable research attention. The identification and characterization of genetic diversity, as well as identification of the population structure of accessions preserved in germplasm banks are fundamental for the success of any breeding program. The objective of this study was to evaluate the genetic variability of $10 \mathrm{M}$. dubia populations obtained from the shores of Reis Lake, located in the municipality of Caracaraí, Roraima, Brazil. Fourteen polymorphic inter simple sequence repeat (ISSR) markers were used to study the population genetic diversity, which resulted in 108 identified alleles. Among the 14 primers, GCV, UBC810, and UBC827 produced the highest number of alleles. The study illustrated the suitability and efficiency of ISSR markers to study the genetic diversity of M. dubia accessions. We also revealed the existence of high genetic variability among both accessions and populations that can be exploited in future breeding programs and conservation activities of this species.

Key words: Myrciaria dubia; Myrtaceae; Genetic diversity; Native fruits; ISSR; Conservation

\section{INTRODUCTION}

The Amazon is a unique territory in the world that harbors tremendous variability of flora and fauna. It extends along nine South American countries, with Brazil being the country with the largest territorial representation. In Brazil, the Amazon region stretches across several states. The state of Roraima provides important shelter for fruit tree species not yet known or underutilized. Most of the fruit species in this wild, little populated region, provide fruits with high social and economic value. This economic and social value can be increased through direct selection or through the process of breeding. Myrciaria dubia, belonging to the Myrtaceae family, is one such species. It is commonly known as camu-camu in Peru; camucamu, caçari, and araçá-d'água in Brazil; guayabo in Colombia; and guayabato or guayabito in Venezuela (Pinedo et al., 2004). The species is found in the wild form in all of these countries.

Myrciaria dubia produces tart fruits used to prepare juice, jam, sweets, and ice-cream. It is also known to have a higher vitamin $\mathrm{C}$ content than most other plant species grown in Brazil (Rodrigues et al., 2001; Teixeira et al., 2004; Chagas et al., 2012a). For these reasons, the species has attracted the interest of both consumers and producers. Expanding its production and exploiting its potential in the Amazon region requires designing well-planned breeding programs that focus on collection, conservation, and characterization both of the available germplasm and its center of diversity. Therefore, the first step should be to develop methods to study the genetic diversity of Myrciaria dubia. This step will be of great importance for the success of future breeding programs and will enable the exploitation of genetic resources in a rational manner that will benefit the society.

To study genetic diversity using molecular marker techniques is one way to study genetic differences at the DNA level that, unlike phenotypic markers, is not affected by environmental factors. In the state of Roraima, studies have been conducted to investigate the genetic variability in Myrciaria dubia based on agronomic and morphological characteristics.

Genetics and Molecular Research 16 (1): gmr16019409 
However, there is still a lack of information generated using molecular marker techniques for this species (Lozano, 2013). Information based on molecular markers is therefore essential to promote the conservation of the genetic resources and the identification of new genes of interest. Molecular marker techniques, such as those involving inter simple sequence repeat (ISSR) markers, have contributed significantly as a tool for studying the population structure of biological samples in different crop species. Such markers are widely used because they are efficient, reproducible, fast, and able to identify high numbers of polymorphisms in a given population (Pradeep Reddy et al., 2002; Kuras et al., 2004).

Studies of population structure and genetic diversity in natural populations of other Myrtaceae family plants have been conducted using ISSR markers. Santana et al. (2016) used ISSR markers to study the genetic diversity of Myrciaria tenella and found 71 polymorphic bands. Brandão et al. (2011) evaluated the genetic structure of Myrcia splendens using 10 ISSR markers and found 70 polymorphic bands. However, in Myrciaria dubia there is limited information about the variability in molecular marker patterns. This fact hinders the progress of breeding programs and conservation activities of this species. For this reason, it is very important to conduct further studies that use molecular markers, especially using Myrciaria dubia populations collected from its center of diversity (the Amazon). This study was done with the objective of studying the genetic diversity among 94 accessions of Myrciaria dubia collected along the shores of Reis Lake located in the municipality of Caracaraí, Roraima, Brazil, using ISSR markers.

\section{MATERIAL AND METHODS}

\section{Plant material and DNA extraction}

We collected and identified young, completely expanded leaves of 94 accessions of Myrciaria dubia. These accessions represented 10 populations grown in germplasm banks on the shore of Reis Lake (latitude of $1^{\circ} 30^{\prime} 10.44^{\prime \prime}$ North, $61^{\circ} 15^{\prime} 44.64 "$ West, at an altitude of $74 \mathrm{~m}$ ), in the middle Rio Branco, located in the municipality of Caracaraí, Roraima, Brazil (Figure 1). The size of the selected populations only allowed for collection of a maximum of 11 individuals. The leaves were stored at $-80^{\circ} \mathrm{C}$ for at least $2 \mathrm{~h}$ where after DNA was extracted using the methodology described by Nunes et al. (2011).

\section{ISSR marker analysis}

Fourteen ISSR markers were selected, based on their polymorphisms, and used in this study to analyze the genetic diversity among the Myrciaria dubia populations (Table 1). The DNA amplifications were performed in a thermal cycler gradient (Gradient Multigene; Labnet International, USA). The final reaction volume was $25 \mu \mathrm{L}$, containing $20 \mathrm{mM}$ Tris- $\mathrm{HCl} \mathrm{pH}$ 8.3, $1.5 \mathrm{mM} \mathrm{MgCl}, 100 \mathrm{mM} \mathrm{KCl}, 0.10 \%$ Triton X-100, $200 \mu \mathrm{M}$ each deoxyribonucleotide triphosphate (dNTP), $0.8 \mu \mathrm{M}$ primer, $1.5 \mathrm{U}$ enzyme GoTaq Flexi DNA polymerase (Prodimol, USA), and $50 \mathrm{ng}$ DNA. In the polymerase chain reactions (PCR), the samples were initially subjected to $95^{\circ} \mathrm{C}$ for $2 \mathrm{~min}$, followed by 40 amplification cycles consisting of $95^{\circ} \mathrm{C}$ for $45 \mathrm{~s}$, $1 \mathrm{~min}$ annealing temperature (ranging from $47-52^{\circ} \mathrm{C}$, depending on the primer used), and an extension step at $72^{\circ} \mathrm{C}$ for $2 \mathrm{~min}$. After the cycles, the samples were kept at $72^{\circ} \mathrm{C}$ for $5 \mathrm{~min}$ for final extension. The PCR products were separated on a $1.5 \%$ agarose gel containing $0.2 \mathrm{mg} /$

Genetics and Molecular Research 16 (1): gmr16019409 
$\mathrm{mL} \mathrm{EtBr} \mathrm{(ethidium} \mathrm{bromide)} \mathrm{using} \mathrm{horizontal} \mathrm{gel} \mathrm{electrophoresis} \mathrm{run} \mathrm{at} 100 \mathrm{mV}$ for at least $3 \mathrm{~h}$ in $1 \mathrm{X}$ TBE buffer. All gels were visualized and recorded using a UV image digitalizer (Uvitec, USA).

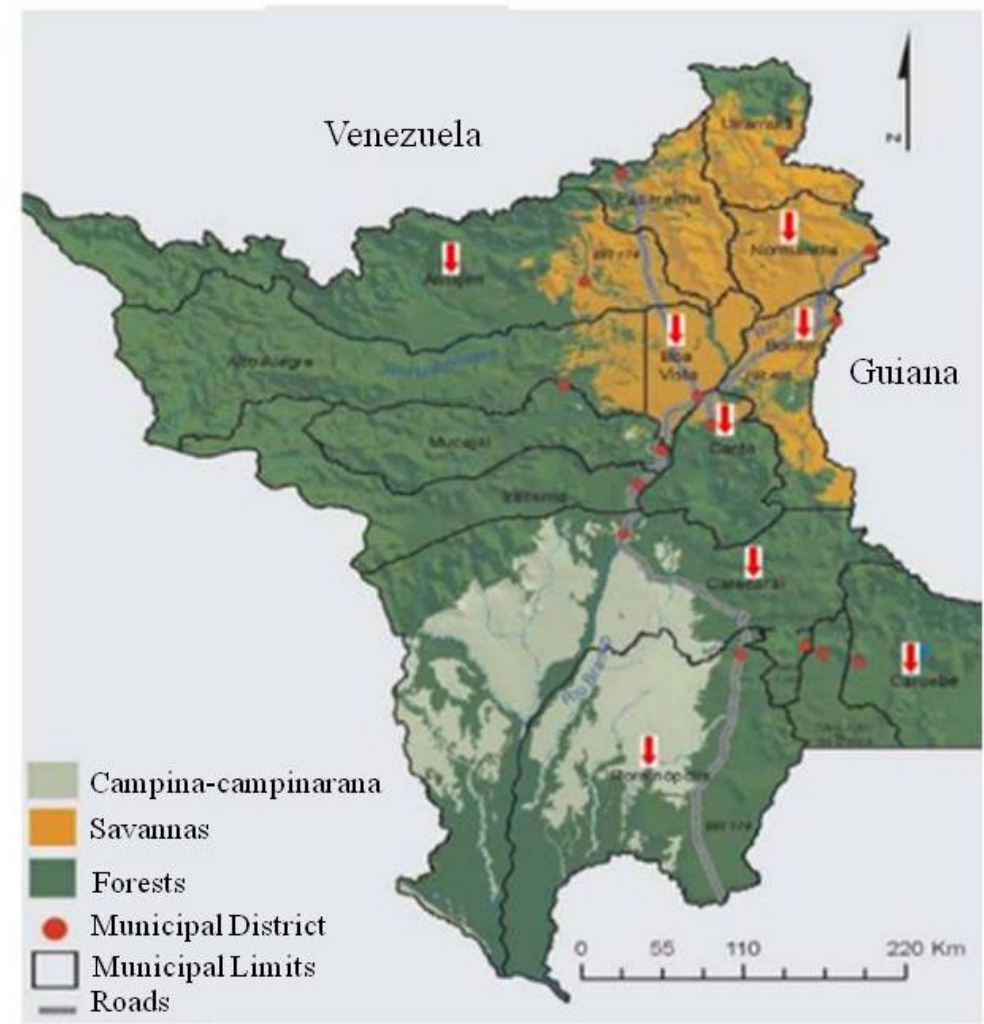

Figure 1. Map of the Caracaraí municipality region and other cities in the state of Roraima showing the occurrence of camu-camu (Myrciaria dubia) as indicated by arrows. UFRR, Boa Vista-RR, 2012. Source: Chagas et al. (2012b).

Table 1. Name, primer sequence, motif, annealing temperature $(T)$, and references for the ISSR markers used in this study.

\begin{tabular}{|c|c|c|c|c|}
\hline Name & Primer sequence $\left(5^{\prime}-3^{\prime}\right)$ & Motif & $\mathrm{T}\left({ }^{\circ} \mathrm{C}\right)$ & Reference \\
\hline UBC810 & GAGAGAGAGAGAGAGAT & $(\mathrm{GA})_{8} \mathrm{~T}$ & $52 ; 44.6$ & Martins-Lopes et al. (2007); Alizadeh et al. (2008) \\
\hline UBC812 & GAGAGAGAGAGAGAGAA & $(\mathrm{GA})_{8} \mathrm{~A}$ & 51.6 & Alizadeh et al. (2008) \\
\hline UBC827 & ACACACACACACACACG & $(\mathrm{AC})_{8} \mathrm{G}$ & 50 & Casu et al. (2005) \\
\hline UBC850 & GTGTGTGTGTGTGTGTYC & $(\mathrm{GT})_{8} \mathrm{YC}$ & 52 & Moreno et al. (1998) \\
\hline UBC855 & ACACACACACACACACYT & $(\mathrm{AC})_{8} \mathrm{YT}$ & 52 & Dhanorkar et al. (2005) \\
\hline UBC856 & ACACACACACACACACYA & $(\mathrm{AC}) 8 \mathrm{YA}$ & 48 & Nascimento et al. (2010) \\
\hline UBC857 & ACACACACACACACACYG & $(\mathrm{AC})_{8} \mathrm{YG}$ & $52 ; 54.3$ & Moreno et al. (1998); Alizadeh et al. (2008) \\
\hline UBC890 & VHV GTGTGTGTGTGTGTT & $\mathrm{VHV}(\mathrm{GT})_{7} \mathrm{~T}$ & 52 & Moreno et al. (1998) \\
\hline UBC891 & HVH TGTGTGTGTGTGTG & $\mathrm{HVH}(\mathrm{TG})_{7}$ & $52 ; 51.6$ & Moreno et al. (1998); Alizadeh et al. (2008) \\
\hline VBV & VBVACACACACACACAC & $\mathrm{VBV}(\mathrm{AC})_{7}$ & 51 & Arnau et al. (2003) \\
\hline BDV & BDVAGAGAGAGAGAGAG & $\mathrm{BDV}(\mathrm{AG})_{7}$ & 47 & Arnau et al. (2003) \\
\hline $\mathrm{HBH}$ & HBHCTCTCTCTCTCTCT & $\mathrm{HBH}(\mathrm{CT})_{7}$ & 47 & Arnau et al. (2003) \\
\hline BDB & BDBCACACACACACACA & $\mathrm{BDB}(\mathrm{CA})_{7}$ & 51 & Arnau et al. (2003) \\
\hline GCV & GCVTCTCTCTCTCTCTC & $\mathrm{GCV}(\mathrm{TC})_{7}$ & 49 & Arnau et al. (2003) \\
\hline
\end{tabular}

Genetics and Molecular Research 16 (1): gmr16019409 


\section{Data analysis}

The patterns of the amplified ISSR fragments behaved as dominant markers and were tabulated as binary data, scored as present (1) or absent (0) for all accessions and for each locus. The molecular weight of each fragment was estimated with reference to a DNA marker ladder [50 bp DNA Ladder $50 \mathrm{mg}(1.0 \mathrm{mg} / \mu \mathrm{L})$, Invitrogen, USA].

To study the genetic diversity, Nei's genetic diversity index (Nei, 1973), Shannon's information index, and percent polymorphic bands $(\mathrm{P} \%)$ were estimated using Popgene software v. 1.3 (Yeh and Boyle, 1997). A principal coordinate analysis (PCoA) and analysis of molecular variance (AMOVA) were performed using GenAlex 6.1 software (Peakall and Smouse, 2006). Using the Convert software (Glaubitz, 2004), we estimated the allele frequencies for all loci. This software was also used to convert the genotype data to a format suitable for Structure 2.3.1 (Pritchard et al., 2000). Using Structure 2.3.1, we then analyzed the genetic structure of the 94 accessions and determined the likely number of groups $(\mathrm{K})$, using a Bayesian-based statistical analysis clustering method. The analysis was done with a burn-in period of 10,000 followed by 100,000 MCMC iterations, using an admixture model. This model was run for each $\mathrm{K}$, ranging from two to 12, with 20 independent models runs for each K. The results obtained from Structure were used to determine the appropriate number of clusters using Structure Harvester (Earl and vonHoldt, 2012).

\section{RESULTS}

To ensure reproducibility of the standard ISSR bands, two independent amplifications were performed for each ISSR primer (Figure 2), which indicated reliability of the primers.

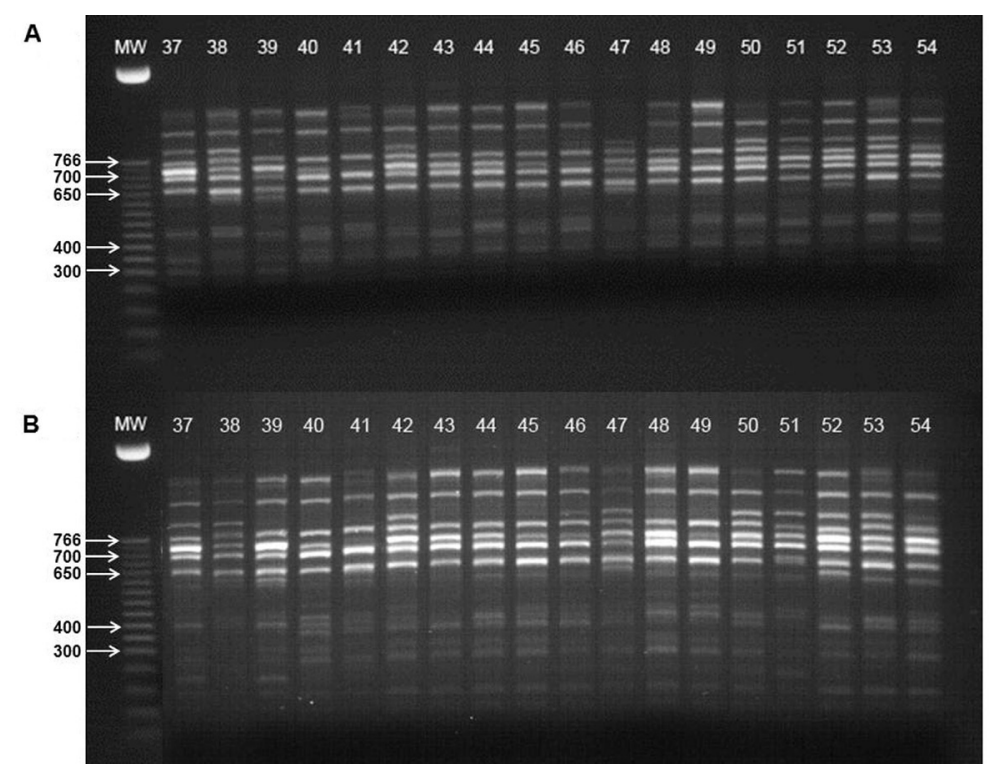

Figure 2. Reproducibility of the PCR reaction with primer UBC 810 on $1.5 \%$ agarose gel stained with $\operatorname{EtBr}(0.2$ $\mathrm{mg} / \mathrm{mL}$ ) showing two independent amplifications of Myrciaria dubia samples (A and B). Arrows indicate countable DNA bands. MW represents the molecular weight marker (50 bp DNA ladder). 
The 14 ISSR primers produced a total of 108 amplified fragments. The number of fragments identified for each primer ranged from four (primer VBV) to 10 (primers GCV, UBC810, and UBC827) with an average of seven fragments per primer (Table 2). In our study, all 108 bands generated by 14 ISSR primers were polymorphic, suggesting that they are suitable for exploration of the between and within population genomic variation of the 94 accessions.

Table 2. Number of bands generated for each ISSR primer used to amplify the DNA of 94 Myrciaria dubia
accessions.
\begin{tabular}{l|c|c|c}
\hline Primer & Number of bands & Primer & Number of bands \\
\hline BDB & 6 & UBC827 & 6 \\
\hline BDV & 9 & UBC850 & 6 \\
\hline GCV & 10 & UBC855 & 6 \\
\hline HBH & 7 & UBC856 & 6 \\
\hline VBV & 4 & UBC857 & 9 \\
\hline UBC810 & 10 & UBC890 & 7 \\
\hline
\end{tabular}

The estimated between population genetic diversity parameters are present in Table 3 . The highest allele frequency and effective number of alleles were found in populations RL2, RL15, and RL4. These same populations were also identified as having the highest genetic diversity and percentage of polymorphism. This suggests that these populations have higher intra-population diversity than the other populations.

Table 3. Observed number of alleles $\left(N_{\mathrm{A}}\right)$, effective e number of alleles $\left(N_{\mathrm{E}}\right)$, Nei's genetic diversity index $(\mathrm{H})$, Shannon's information index (I), total number of polymorphic bands, and percent polymorphism $(\mathrm{P} \%)$ for each of the ten evaluated populations. RL: Reis Lake, the sample origin.

\begin{tabular}{l|c|c|c|c|c|c|c}
\hline Population ID & Sample size & $N_{\mathrm{A}}$ & $N_{\mathrm{E}}$ & $\mathrm{H}$ & $\mathrm{I}$ & No. of polymorphic bands & P\% \\
\hline RL1 & 10 & 1.5833 & 1.3286 & 0.1967 & 0.2982 & 63 & 58.33 \\
\hline RL2 & 10 & 1.6481 & 1.4149 & 0.2393 & 0.355 & 70 & 64.81 \\
\hline RL3 & 8 & 1.4722 & 1.3117 & 0.1782 & 0.2636 & 51 & 47.22 \\
\hline RL4 & 11 & 1.6296 & 1.4386 & 0.2479 & 0.3631 & 68 & 62.96 \\
\hline RL6 & 10 & 1.537 & 1.3346 & 0.1956 & 0.2916 & 58 & 53.70 \\
\hline RL7 & 10 & 1.5463 & 1.3198 & 0.1894 & 0.2854 & 59 & 54.63 \\
\hline RL8 & 8 & 1.6019 & 1.3439 & 0.2052 & 0.3109 & 65 & 60.19 \\
\hline RL9 & 9 & 1.5463 & 1.3438 & 0.1989 & 0.2963 & 59 & 54.63 \\
\hline RL11 & 10 & 1.5648 & 1.3358 & 0.1993 & 0.2995 & 61 & 56.48 \\
\hline RL15 & 8 & 1.6389 & 1.3561 & 0.2171 & 0.3301 & 69 & 63.89 \\
\hline All & 94 & 1.9907 & 1.5864 & 0.3402 & 0.5069 & & 108 \\
\hline
\end{tabular}

For the analysis of molecular variance (AMOVA), the accessions grouped into 10 groups based on their regions of collection. The genetic variability was found to be 65 and $35 \%$ within and among populations, respectively (Table 4). This indicates that the populations have higher intra-population diversity than inter-population diversity. In addition, it also suggests a high level of differentiation among the populations considered.

The PCoA grouped the Myrciaria dubia populations into three groups (Figure 3). The graphical illustration of the PCoA analysis clearly shows that the samples are grouped based on their respective populations of origin. In addition, accessions collected in nearby regions grouped together, indicating some level of genetic material exchange among them. The results of this analysis showed that $61.93 \%$ of the total variation was explained by the 
first two principal coordinates, with the first coordinate explaining $40.91 \%$, and the second coordinate explaining $21.02 \%$ (data not shown).

\section{Table 4. Analysis of molecular variance among and within Myrciaria dubia populations.}

\begin{tabular}{l|c|c|c|c}
\hline Source & d.f. & Sum of squares & Mean square & $\%$ variation \\
\hline Among pops & 9 & 672.7 & 74.7 & 35 \\
\hline Within pops & 84 & 1054.2 & 12.5 & 65 \\
\hline Total & 93 & 1726.9 & 19.2 & \\
\hline
\end{tabular}

Principal Coordinates (PCoA)

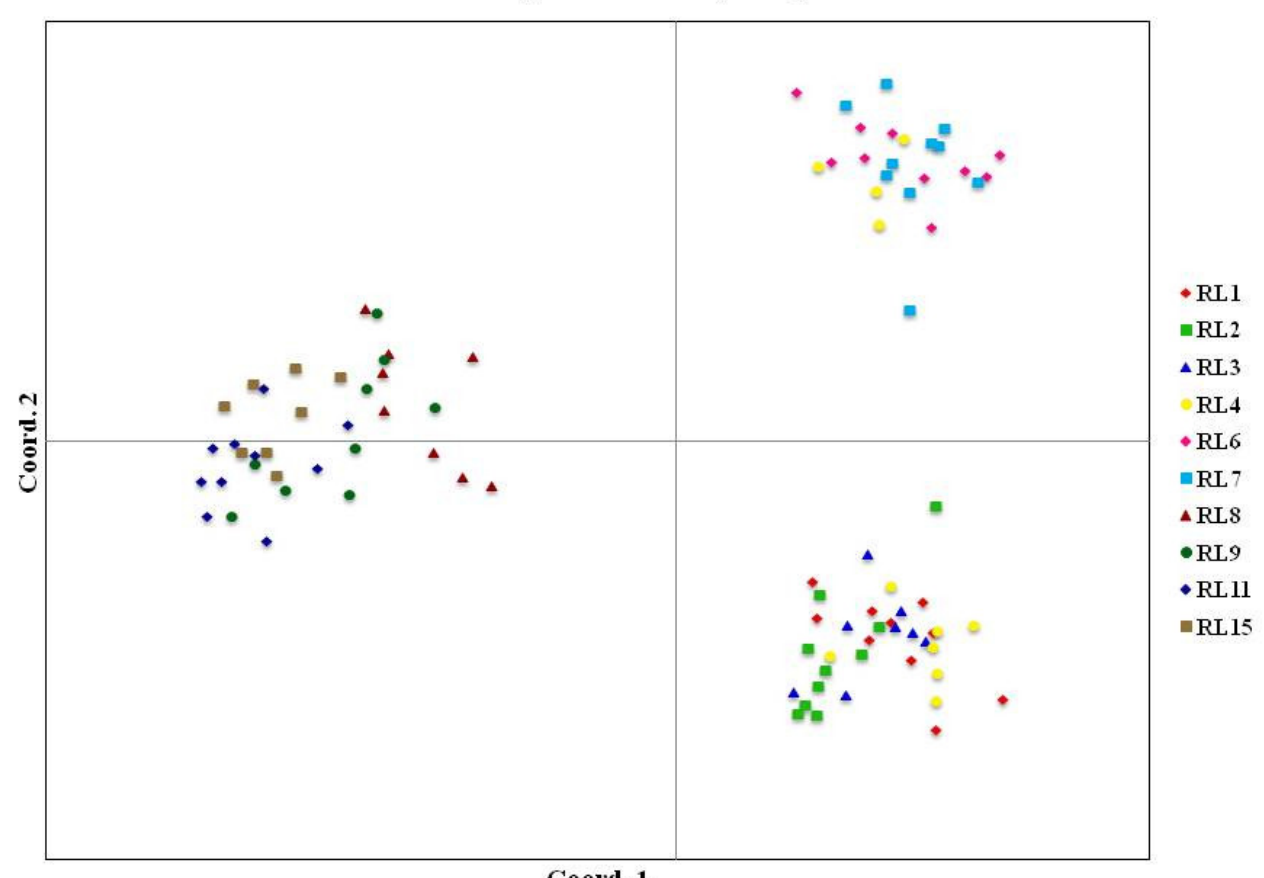

Coord. 1

Figure 3. Principal coordinate analysis of the 94 Myrciaria dubia accessions using the data produced by the 14 ISSR molecular marker.

We found that accessions from population RL4 were distributed both in group 1 and group 2 as identified in the PCoA. In group 3, the populations showed a dispersive behavior, which indicates the existence of genetic diversity among these accessions. By contrast, accessions in groups 1 and 2 tended to group more closely, indicating a greater genetic similarity among accessions within these groups.

Similar to the PCoA, the Bayesian-based clustering analysis also divided the populations into three principal groups $(\mathrm{K}=3)$, according to the criterion of Evanno et al. (2005) (Figure 4). The output from the Structure Harvester software is represented as Group 1 (red); Group 2 (blue), and Group 3 (green). Groups 1 and 3 contained the same number 
of individuals (35), whereas Group 2 comprised 24 individuals. Group 1 was formed by populations (RL1, RL2, RL3, and RL4), Group 2 by populations (RL4, RL6, and RL7), and Group 3 by populations (RL8, RL9, RL11, and RL15). The grouping pattern also indicated some admixture among populations.

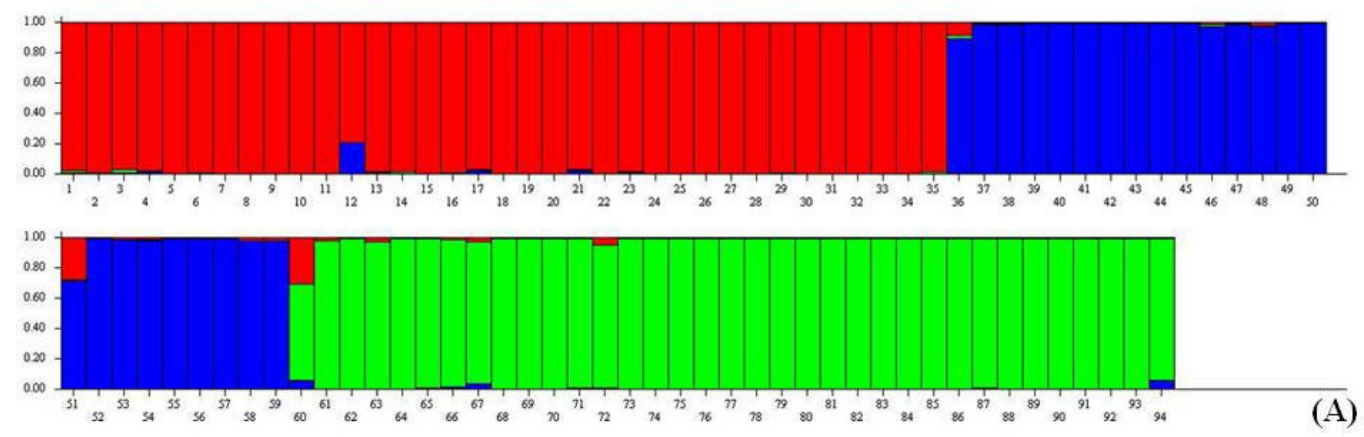

Figure 4. Genetic structure of 94 Myrciaria dubia accessions grouped into three groups (A). Each vertical bar represents an individual accession and the colors represent the three groups defined by the value of K. Bars with more than one color indicate a mixed genetic composition of this accession. The numbers on the $\mathrm{x}$-axis represent the 94 accessions and the y-axis shows the coefficient of "membership".

\section{DISCUSSION}

ISSR markers are dominant and do not require prior knowledge of the genetic sequence of the species under study, i.e. they are not species specific. The occurrence of diversity among the studied individuals using ISSR markers illustrates the efficacy of this technique for studying natural Myrciaria dubia populations. In our study, the proportion of polymorphic fragments produced by the ISSR markers enabled us to detect allelic variation among accessions and permitted further studies of the population structure.

Our results indicated that the Myrciaria dubia populations showed higher genetic variability within than among populations. This may be due to a low exchange of genetic material among the studied populations, since the area where the collections were done were located in the Amazon rainforest where gene flow is very limited due to natural barriers. Due to this fact, we observed a high level (35\%) of among population differentiation. This level of differentiation, which can be considered very high, indicates that each of the studied populations already form their own genetic pools. This can be due to natural barriers in the forest that do not allow for much exchange of genetic material. The Amazon rainforest is very dense, which does not favor the movement of pollen from one population to another through natural events. In accordance with our results, using expressed sequence tag simple sequence repeat markers, Rojas et al. (2011) also found high levels of within population variation (80.3\%) in Myrciaria dubia preserved at the Active Germplasm Bank in Manaus. Similar results were also reported based on microsatellite markers in other Myrtaceae species such as Melaleuca alternifolia with 93\% and Eugenia uniflora with 78.9\% (Rossetto et al., 1999; Salgueiro et al., 2004). According to Hamrick (1983), the distribution of genetic variation is not random within populations; instead, it is determined by the reproductive system, the 
geographical distribution, and the effective population size. Similar to the high genetic diversity observed in this study Nascimento et al. (2014) also reported high genetic diversity based on morphological and agronomical characters. The authors showed high genetic variability among progenies of Myrciaria dubia and recommended a direct selection method to assist the process of domestication and improvement of this species.

The low level of domestication and current absence of a breeding program in this species can also explain the high genetic diversity observed within populations in this study. To date, there is no well-organized breeding program for this species in Brazil, therefore it has not suffered from directional selection through breeding. There are only few conservation and population characterization activities aimed at this species. It is not possible to determine whether the genetic variation observed within the populations we studied reflects variation in environmental conditions in their place of origin because all the materials were collected from the Reis Lake region, which has a uniform climatic condition. Low human intervention in the region may have helped conservation of the genetic variation created during evolutionary processes over a long period of time. Additional studies will be required to determine the genetic diversity among populations from different regions of the Amazon by including populations from a wider geographical distribution. This could be useful for the implementation of conservation programs and management of the species in this region.

Peters and Vásquez (1987) reported that, despite having hermaphrodite flowers, Myrciaria dubia is a facultative allogamous species with over $90 \%$ cross-fertilization and $10 \%$ self- fertilization, which favors heterozygosity. This can explain the observed high within population genetic diversity, since individuals of allogamous species are expected to possess high level of heterozygosity. From this it can be inferred that, in a plant population that reproduces through open pollination, the expected result is heterozygosity at most loci under consideration. Consequently, the populations are expected to show high heterozygosity and to present high variability between individuals of the same population. This may be a likely explanation for the obtained results in this study.

The efficiency of using Bayesian statistics for the genetic diversity and populations structure analyses is well-known and has been used in different crops, such as olive (do Val et al., 2012), coffee (Setotaw et al., 2010), and strawberry (Nunes et al., 2013). In our study, the 94 accessions were grouped into three clusters that agreed with the geographical distribution of the populations. This again suggests a potentially limited genetic exchange among more distant populations through natural pollinating agents. We did also observed some admixture among groups (Figure 4), although the grouping patterns were well defined, in general. Most of the accessions within a group had a membership coefficient $>80 \%$. This illustrates the efficiency of the Bayesian statistical analysis in grouping the accessions in this study. The grouping of different populations in the same groups, as shown in Figure 4, may be due to the proximity of the collection sites of the populations under study.

In a natural population of Myrciaria dubia, found on the riverbanks of Reis Lake, Pinedo et al. (2004) reported high phenotypic variability in various morphological, physiological, and agronomic aspects. It is believed that this species has potential for the establishment of agricultural production systems in flood prone areas of the Brazilian and Peruvian Amazon. Furthermore, it provides additional income for farmers in these regions since the crop has high nutritional value, including a high vitamin $\mathrm{C}$ content, and is frequently used in the production of ice-cream. The results obtained in this study will allow us to provide a better scientific knowledge for future exploitation of the species for commercial

Genetics and Molecular Research 16 (1): gmr16019409 
use in the medium and long term, through the establishment of plantations, conservation, and selection of the best genetic material.

The results reported in this work provide valuable information and knowledge about the genetic constitution of populations collected from the Reis Lake region of the Amazon forest that can be further explored in future research. We evaluated the accessions at the molecular level, which is not influenced by environmental effects like morphological markers. This indicates the importance this work. Therefore, these results provide an opportunity to conduct field trials in a more targeted manner, focusing mainly on the most divergent individuals to start breeding programs in this species. If the objective is selecting genotypes with better agronomic performance, the selection should be performed based not only on their phenotypic responses but also on their genetic constitution. In addition, the information generated from this work will also be valuable for the development of appropriate conservation strategies, which may be important for future agricultural activities in this region. It is also important to highlight that the Myrciaria dubia populations located on the river banks and around lakes in the municipality of Caracaraí are also found in the wild state. Therefore, generating information on collections of the Myrciaria dubia from this region as reported here will help to promote their domestication, conservation, and utilization.

\section{Conflicts of interest}

The authors declare no conflict of interest.

\section{ACKNOWLEDGMENTS}

The authors would like to thank the Coordination of Improvement of Higher Education personnel (CAPES), the National Council for Scientific and Technological Development $(\mathrm{CNPq})$, and Minas Gerais Research Foundation (FAPEMIG) for project funding and scholarships.

\section{REFERENCES}

Alizadeh M, Singh SK, Jhang T and Sharma TR (2008). Inter simple sequence repeat analysis to confirm genetic stability of micropropagated plantlets in three grape (Vitis spp) rootstock genotypes. J. Plant Biochem. Biotechnol. 17: 77-80. http://dx.doi.org/10.1007/BF03263264

Arnau G, Lallemand J and Bourgoin M (2003). Fast and reliable strawberry cultivar identification using inter simple sequence repeat (ISSR) amplification. Euphytica 129: 69-79. http://dx.doi.org/10.1023/A:1021509206584

Brandão MM, Vieira FA and Carvalho D (2011). Estrutura genética em microescala espacial de Myrcia splendens (Myrtaceae). Rev. Arvore 35: 957-964. http://dx.doi.org/10.1590/S0100-67622011000600001

Casu M, Maltagliati F, Cossu P, Lai T, et al. (2005). Fine-grained spatial genetic structure in the bivalve Gemma gemma from Maine and Virginia (USA), as revealed by Inter-Simple Sequence Repeat markers. J. Exp. Mar. Biol. Ecol. 325: 46-54. http://dx.doi.org/10.1016/j.jembe.2005.04.020

Chagas EA, Bacelar-Lima CG, Carvalho AS, Ribeiro MIG, et al. (2012a). Propagação do camu-camu (Myrciaria dubia (H.B.K.) McVaugh).Rev.Agro@mbiente 6: 67-73.

Chagas EA, Carvalho AS, Bacelar-Lima G, Duarte OR, et al. (2012b). Distribuição geográfica de populações nativas de camu-camu no Estado de Roraima. XXII Congresso brasileiro de fruticultura. Bento Goncalves-RS. Anais do XXII Congresso Brasileiro de Fruticultura 3861-3864

Dhanorkar VM, Tamhankar SA, Patil SG and Rao VS (2005). ISSR-PCR for assessment of genetic relationships among grape varieties cultivated in India. Vitis 44: 127-131.

do Val AD, Ferreira JL, Vieira Neto J, Pasqual M, et al. (2012). Genetic diversity of Brazilian and introduced olive

Genetics and Molecular Research 16 (1): gmr16019409 
germplasms based on microsatellite markers. Genet. Mol. Res. 11: 556-571. http://dx.doi.org/10.4238/2012. March.8.4

Earl DA and vonHoldt BM (2012). STRUCTURE HARVESTER: a website and program for visualizing structure output and implementing the Evanno method. Conserv. Genet. Resour. 4: 359-361. http://dx.doi.org/10.1007/s12686-011-9548-7

Evanno G, Regnaut S and Goudet J (2005). Detecting the number of clusters of individuals using the software STRUCTURE: a simulation study. Mol. Ecol. 14: 2611-2620. http://dx.doi.org/10.1111/j.1365-294X.2005.02553.x

Glaubitz JC (2004). CONVERT: a user-friendly program to reformat diploid genotypic data for commonly used population genetic software packages. Mol. Ecol. 4: 309-310. http://dx.doi.org/10.1111/j.1471-8286.2004.00597.x

Hamrick JL (1983). The distribution of genetic variation within and among natural forest populations. In: Genetics and conservation (Schonewald-Cox CM, Chambers SM, McBryde B and Thomas WL, eds.). Benjamin/Cummings, Menlo Park, 335-348.

Kuras A, Korbin M and Żurawicz E (2004). Comparison of suitability of RAPD and ISSR techniques for determination of strawberry (Fragaria x ananassa Duch.) relationship. Plant Cell Tissue Organ Cult. 79: 189-193. http://dx.doi. org/10.1007/s11240-004-0659-7

Lozano RMB (2013). Caracterização intraespecífica da variabilidade biométrica de frutos em populações nativas de camu-camu. Master's thesis, Universidade Federal de Roraima, Boa Vista. Available at [http://www.bdtd.ufrr.br/ tde_arquivos/2/TDE-2013-05-09T073224Z-116/Publico/RicardoManuelBardalesLozano.pdf]

Martins-Lopes P, Lima-Brito J, Gomes S, Meirinhos J, et al. (2007). RAPD and ISSR molecular markers in Olea europaea L.: Genetic variability and molecular cultivar identification. Genet. Resour. Crop Evol. 54: 117-128. http://dx.doi. org/10.1007/s10722-005-2640-7

Moreno S, Martín JP and Ortiz JM (1998). Inter-simple sequence repeats PCR for characterization of closely related grapevine germplasm. Euphytica 101: 117-125. http://dx.doi.org/10.1023/A:1018379805873

Nascimento MA, Batalha-Filho H, Waldschmidt AM, Tavares MG, et al. (2010). Variation and genetic structure of Melipona quadrifasciata Lepeletier (Hymenoptera, Apidae) populations based on ISSR pattern. Genet. Mol. Biol. 33: 394-397. http://dx.doi.org/10.1590/S1415-47572010005000052

Nascimento WMO, Gurgel FL, Bhering LL and Ribeiro OD (2014). Pré-melhoramento do camucamuzeiro: estudo de parâmetros genéticos e dissimilaridade. Rev. Ceres 61: 538-543. http://dx.doi.org/10.1590/0034-737X201461040013

Nei M (1973). Analysis of gene diversity in subdivided populations. Proc. Natl. Acad. Sci. USA 70: 3321-3323. http:// dx.doi.org/10.1073/pnas.70.12.3321

Nunes CF, Ferreira JL, Fernandes MCN, Breves SS, et al. (2011). An improved method for genomic DNA extraction from strawberry leaves. Cienc. Rural 41: 1383-1389. http://dx.doi.org/10.1590/S0103-84782011000800014

Nunes CF, Ferreira JL, Generoso AL, Dias MSC, et al. (2013). The genetic diversity of strawberry (Fragaria ananassa Duch.) hybrids based on ISSR markers. Acta Sci. Agron. 35: 443-452. http://dx.doi.org/10.4025/actasciagron.v35i4.16737

Peakall R and Smouse PE (2006). GENALEX 6: genetic analysis in Excel. Population genetic software for teaching and research. Mol. Ecol. Notes 6: 288-295. http://dx.doi.org/10.1111/j.1471-8286.2005.01155.x

Peters CM and Vásquez MA (1987). Estudios ecológicos de camu-camu (Myrciaria dubia). I. Producción de frutos en poblaciones naturales. Acta Amazon. 17: 161-188. http://dx.doi.org/10.1590/1809-43921987171174

Pinedo M, Linares C, Mendoza H and Anguiz R (2004). Plan de mejoramiento genético de camu-camu. Instituto de Investigaciones de la Amazonia Peruana, Iquitos, Peru.

Pradeep Reddy M, Sarla N and Siddiq EA (2002). Inter simple sequence repeat (ISSR) polymorphism and its application in plant breeding. Euphytica 128: 9-17. http://dx.doi.org/10.1023/A:1020691618797

Pritchard JK, Stephens M and Donnelly P (2000). Inference of population structure using multilocus genotype data. Genetics 155: 945-959.

Rodrigues RB, de Menezes HC, Cabral LMC, Dornier M, et al. (2001). An Amazonian fruit with a high potential as a natural source of vitamin C: the camu-camu (Myrciaria dubia). Fruits 56: 345-354. http://dx.doi.org/10.1051/ fruits: 2001135

Rojas S, Ch YKC and Nagao EO (2011). Diversidade genética em acessos do banco de germoplasma de camu-camu (Myrciaria dúbia [H.B.K.] McVaugh) do INPA usando marcadores microssatélites (EST-SSR). Rev. Corpoica Cienc. Tecnol. Agropec. 12: 51-64. http://dx.doi.org/10.21930/rcta.vol12_num1_art:215

Rossetto M, Slade RW, Baverstock PR, Henry RJ, et al. (1999). Microsatellite variation and assessment of genetic structure in tea tree (Melaleuca alternifolia-Myrtaceae). Mol. Ecol. 8: 633-643. http://dx.doi.org/10.1046/j.1365294x.1999.00622.x

Salgueiro F, Felix D, Caldas JF, Margis-Pinheiro M, et al. (2004). Even population differentiation for maternal and biparental gene markers in Eugenia uniflora, a widely distributed species from the Brazilian coastal Atlantic rain forest. Divers. Distrib. 10: 201-210. http://dx.doi.org/10.1111/j.1366-9516.2004.00078.x

Genetics and Molecular Research 16 (1): gmr16019409 
Santana JG, Nascimento AL, Costa TS and de Almeida TM (2016). Estimation of genetic diversity in a natural population of cambuci tree (Myrciaria tenella O. Berg) using ISSR markers. Genet. Mol. Res. 15: http://dx.doi.org/10.4238/ gmr.15048819.

Setotaw TA, Caixeta ET, Pena GF, Zambolim EM, et al. (2010). Breeding potential and genetic diversity of "Híbrido do Timor" coffee evaluated by molecular markers. Crop Breed. Appl. Biotechnol. 10: 298-304.

Teixeira AS, Chaves LS and Yuyama K (2004). Esterases no exame da estrutura populacional de Camu-camu (Myrciaria dubia (Kunth) McVaugh-Myrtaceae). Acta Amazon. 34: 75-88. http://dx.doi.org/10.1590/S0044-59672004000100011

Yeh FC and Boyle TJB (1997). Population genetic analysis of co-dominant and dominant markers and quantitative traits. Belg. J. Bot. 129: 157-163.

Genetics and Molecular Research 16 (1): gmr16019409 